\title{
Politik Hukum Perundang-Undangan Pasar Modal Syariah di Indonesia
}

\author{
Adirianto \\ Fakultas Syariah UIN Maulana Malik Ibrahim Malang \\ adirianto@gmail.com
}

\begin{abstract}
:
This article aims to describe how the policy formation of Islamic Capital Market Law in Indonesia. This article is based on research using the normative approach to law (statute approach) and the conceptual approach (conceptual approach). The results of the discussion of this article shows that the formation of Law No. 8 of 1995 on Capital Market from the approach used in the Draft Law on Capital Market is divided into two, namely the Institutional Approach and Approach Activities. From that approach then can the problem to design the Law on Capital Market that have been showcased in the Problem Inventory List (DIM) to conduct further discussion process in the Establishment Act Concerning the Capital Market. Other factors are reflected in very strong sociological aspects of coverage that would pihakpihak governed by this Law which covers all players in the capital market, which is any party that has an interest in the activity modalan outlets and public companies.
\end{abstract}

Artikel ini bertujuan mendeskripsikan bagaimana kebijakan pembentukan Undangundang Pasar Modal Syariah di Indonesia. Artikel ini berdasarkan penelitian normatif dengan menggunakan pendekatan perundang-undangan (statute approach) dan pendekatan konseptual (conceptual approach). Hasil pembahasan artikel ini menunjukkan bahwa terbentuknya Undang-Undang No. 8 Tahun 1995 tentang Pasar Modal dari pendekatan yang digunakan dalam Rancangan Undang-undang tentang Pasar Modal dibagi dua, yaitu Pendekatan Kelembagaan dan Pendekatan Aktivitas. Dari pendekatan itu maka di dapat masalah untuk merancang Undang-Undang tentang Pasar Modal yang sudah di tuangkan dalam Daftar Inventarisasi Masalah (DIM) untuk melakukan Proses Pembahasan selanjutnya dalam Pembentukan Undang-Undang Tentang Pasar Modal. Faktor lainnya secara aspek sosiologisnya tercermin sangat kuat dari cakupan pihakpihak yang kelak diatur oleh Undang-Undang ini yang mencakup seluruh pelaku Pasar Modal, yaitu setiap pihak yang mempunyai kepentingan dengan aktivitas kepasar modalan dan perusahaan publik.

Kata Kunci: pasar modal syariah; politik hukum; keuangan

\section{Pendahuluan}

Pasar modal (capital market) merupakan pasar untuk berbagai instrument keuangan jangka panjang yang biasa diperjualbelikan, baik dalam bentuk hutang maupun modal sendiri. Jika pasar modal merupakan pasar untuk surat berharga jangka panjang, maka pasar uang (money market) pada sisi yang lain merupakan pasar surat berharga jangka pendek. Adapun instrument keuangan yang diperjual belikan di pasar modal seperti saham, obligasi, warran, right, obligasi konvertibel dan berbagai produk turunan (deviratif) seperti opsi (put atau call), sedangkan dipasar uang diperjual belikan antara lain Sertifikat Bank Indonesia (SBI), Surat Jurisdictie: Jurnal Hukum dan Syariah Vol. 6 No. 2 Desember 2015 
Berharga Pasar Uang (SBPU) dan lain-lain. ${ }^{1}$ Pasar Modal Syariah sebagai pasar modal yang menerapkan prinsipprinsip syariah dalam kegiatan transaksi ekonomi dan terlepas dari hal-hal yang dilarang seperti riba, perjudian, spekulasi, dan lain-lain. Keberadaan pasar modal di Indonesia merupakan salah satu faktor terpenting dalam ikut membangun perekonomian nasional, terbukti telah banyak industri dan perusahaan yang menggunakan institusi pasar modal ini sebagai media untuk menyerap investasi dan media untuk memperkuat posisi keuangannya. $^{2}$

Sejarah pembentukan pasar modal di Indonesia bermula pada zaman VOC yang berlanjut hingga pada masa Indonesia modern. Setelah mendapatkan kemerdekaan pada tahun 1945, Indonesia mulai melakukan pembangunan di berbagai bidang. Pemerintah Indonesia pasca Orde Lama berkonsentrasi pada pembangunan secara lebih sistematis sejak akhir 1960an. Kenyataan yang dihadapi pemerintah saat itu adalah keperluan dana yang teramat besar, sehingga Pemerintah Indonesia mengupayakan penghimpunan dana untuk pembangunan dengan berbagai cara, terutama melalui pinjaman dari sindikasi Negara-negara donor seperti Negara-negara Eropa yang tergabung dalam Inter-Govermental Group on Indonesia (IGGI) (kemudian Consultative Group on Indonesia atau CGI), jepang, dan amerika serikat. ${ }^{3}$

Untuk mengembangkan Pasar Modal Syariah, kebijakan lembaga terkait diwujudkan dalam bentuk Keputusan Ketua Bapepam (Badan Pengawas Pasar Modal). Hingga saat ini, keputusan yang telah dikeluarkan dan menjadi dasar operasional Pasar Modal Syariah ialah Pertama Peraturan IX.A.13 dalam Keputusan Ketua Bapepam-LK Nomor Kep-130/BL/2006 tentang penerbitan efek syariah. ${ }^{4}$ Kemudian disamping kedua peraturan tersebut juga ada peraturan II.K.1 dalam Keputusan Ketua Bapepam Nomor Kep-314/BL/2007 tentang kriteria dan penerbitan daftar efek syariah. Dengan adanya Undang-Undang Pasar Modal No. 8 Tahun 1995 Tentang Pasar Modal (UUPM) pada pasal 1 butir 13 menyatakan bahwa pasar modal adalah kegiatan yang bersangkutan dengan penawaran umum dan perdagangan efek, perusahaan publik yang berkaitan dengan efek yang diterbitkannya, serta lembaga dan profesi yang berkaitan dengan efek. Dasar hukum yang menjadi acuan dalam pelaksanaan Pasar Modal Syariah di Indonesia adalah fatwa-fatwa yang dikeluarkan oleh Dewan Syariah Nasional Majelis Ulama Indonesia (DSNMUI) Nomor 40/DSN-MUI/X/2013 Tentang Pasar Modal dan Pedoman Umum Penerapan Prinsip Syariah di Bidang Pasar Modal serta regulasi yang dikeluarkan oleh Bapepam-LK, hal ini dilakukan guna menghindari terjadinya kerancuan dalam pelaksanaan Pasar Modal Syariah di Indonesia.

Pembentukan Pasar Modal Syariah dapat ditelusuri dari perkembangan pengaturan Pasar Modal Syariah tersebut. Perkembangan tersebut dimulai dari MoU (Memorandum of Understanding) antara Bapepam dan DSN-MUI pada tanggal 14 Maret 2003. MoU menunjukkan adanya kesepahaman antara Bapepam dan DSN-MUI untuk mengembangkan Pasar Modal Syariah di Indonesia. Selanjutnya hal ini dapat dilihat dari fatwa-fatwa DSNMUI yang menjadi acuan pada Pasar Modal Syariah mulai dari tahun 2010 sampai 2011. ${ }^{5}$ Proses atau tata cara pembentukan undang-undang merupakan suatu tahapan kegiatan yang dilaksanakan secara berkesinambungan untuk membentuk undang-undang. Proses ini diawali dari terbentuknya suatu ide atau gagasan tentang perlunya pengaturan terhadap suatu permasalahan, yang kemudian dilanjutkan dengan kegiatan mempersiapkan rancangan Undang-undang baik oleh Dewan Perwakilan Rakyat, oleh Dewan Perwakilan Daerah,

\footnotetext{
${ }^{1}$ Heri Sudarsono, Bank dan Lembaga Keuangan Syariah Deskripsi dan Illustrasi (Yogyakarta: Ekonisia, 2007), 184

${ }^{2}$ Ahmad Rodoni dan Abdul Hamid,. Lembaga Keuangan Syariah. (Jakarta: Zikrul Hakim, 2008), 10

${ }^{3}$ M. Irsan Nasarudin dan Indra Surya, Aspek Hukum Pasar Modal Indonesia (Jakarta: Kencana, 2008), 1

${ }^{4}$ Burhanuddin Susamto, Pasar Modal Syariah (Yogyakarta: UII Pers. 2009), 5

${ }^{5}$ Burhanuddin Susamto Aspek Hukum Lembaga Keuangan Syariah, (Yogyakarta: Graha Ilmu, 2010), 132

Jurisdictie: Jurnal Hukum dan Syariah Vol. 6 No. 2 Desember 2015
} 
maupun oleh Pemerintah, kemudian pembahasan rancangan Undang-Undang di Dewan Perwakilan Rakyat untuk mendapatkan persetujuan bersama, dilanjutkan dengan pengesahan, dan diakhiri dengan perundangan. ${ }^{6}$

Dengan ditetapkannya Keputusan Presiden No. 188 Th. 1998 tentang Tata Cara Mempersiapkan Rancangan Undang-Undang, yang ditetapkan pada tanggal 28 Oktober 1998, maka proses pembentukan undang-undang dilaksanakan dengan berpedoman pada Keputusan Presiden tersebut, sedangkan tata cara mempersiapkan rancangan undang-undang yang berasal dari Dewan Perwakilan Rakyat dan proses pembahasan dari kedua rancangan undangundang di Dewan Perwakilan Rakyat dilaksanakan berdasarkan Keputusan Dewan Perwakilan Rakyat Republik Indonesia No. 03A/DPR RI/2001-2002 tentang Peraturan Tata Tertib Dewan Perwakilan Rakyat Republik Indonesia. ${ }^{7}$ Politik penerapan hukum berkaitan dengan fungsi-fungsi penyelengaraan pemerintahan dibidang hukum. Politik penegakan hukum berkaitan dengan sendi-sendi sistem kenegaraan seperti Negara berdasarkan atas hukum. Secara internal ada 2 (dua) lingkup utama Politik Hukum: (1) Politik pembentukan hukum baik mengenai tata cara maupun isi peraturan perundang-undangan adalah kebijaksanaan yang terkait dengan penciptaan, pembaruan dan pengembangan hukum, mencakup (i) kebijaksanaan (pembentukan) perundang-undangan; (ii) kebijaksanaan (pembentukan) hukum yurisprudensi; (iii) kebijaksanaan terhadap peraturan tidak tertulis; (2) Politik penerapan dan penegakan hukum adalah kebijaksanaan yang bersangkut paut dengan: (a) Kebijaksanaan di bidang peradilan dan cara-cara penyelesaian hukum di luar proses peradilan (arbitrasi, negosiasi atau rekonsialisasi); (b) Kebijaksanaan di bidang pelayanan hukum. ${ }^{8}$

Di sisi lain, pembuatan peraturan perundang-undangan terkait dengan Pasar Modal Syariah tidak terlepas dari adanya politik hukum. Artinya bahwa perundang-undangan itu sendiri merupakan bentuk dari politik hukum (legal policy). Pengertian legal policy, mencakup proses pembuatan dan pelaksanaan hukum yang dapat menunjukkan sifat dan ke arah mana hukum akan dibangun. Dengan kata lain, politik hukum memberikan landasan terhadap proses pembentukan hukum yang sesuai situasi, kondisi, kultur serta nilai yang berkembang di masyarakat dengan memperhatikan kebutuhan masyarakat terhadap hukum itu sendiri. ${ }^{9}$ Berbicara mengenai pendekatan yang ditempuh dalam menyusun Rancangan Undang-Undang tentang Pasar Modal ini, dapat kiranya kami sampaikan bahwa secara garis besar pendekatannya dapat dibagi dua, yaitu Pendekatan Kelembagaan dan Pendekatan Aktivitas. ${ }^{10}$ Pertimbangan memilih untuk memilih Pendekatan Kelembagaan adalah karena keberadaan unsur lembaga terasa sangat kuat di dalam pasal-pasal yang ada. Sebagai contoh: Bapepam adalah sebagai lembaga pengawas, Bursa Efek bertindak sebagai lembaga yang menyelenggarakan pasar sekunder, lembaga Kliring dan Penjaminan serta Lembaga Penyimpanan dan Penyelesaian bertindak sebagai lembaga yang menyelesaikan transaksi bursa, serta keberadaan lembaga-lembaga lainnya seperti Lembaga Penunjang Pasar Modal, dan profesi penunjang Pasar Modal. Sementara Pendekatan aktivitas dapat dilihat dari pasalpasal di dalam Rancangan Undang-Undang ini memuat aktivitas dari setiap lembaga sebagaimana disebutkan diatas. Pembentukan Undang-Undang No. 8 Tahun 1995 Tentang Pasar Modal didasari beberapa hal karena Mengingat bahwa pasar modal merupakan sumber pembiayaan dunia usaha dan sebagai media investasi bagi para pemodal yang ingin memiliki

\footnotetext{
${ }^{6}$ Maria Farida Indrati, Ilmu Perundang-Undangan 2 "Proses dan Tekhnik Pembentukannya", (Yogyakarta,

Penerbit Kanisius, 2007), 10

${ }^{7}$ Maria Farida Indrati, Ilmu Perundang-Undangan 2, 10

${ }^{8}$ Abdul Latif dan Hasbi Ali, Politik Hukum (Jakarta, Sinar Grafika, 2010), 165

${ }^{9}$ Abdul Latif dan Hasbi Ali, Politik Hukum, 19

10 Dewan Perwakilan Rakyat Republik Indonesia “Arsip Dokumentasi Setjen DPR RI 2012 Risalah Rapat

Panitia Khusus Rancangan Undang-Undang Tentang Pasar Modal Tahun 1995”, 25
}

Jurisdictie: Jurnal Hukum dan Syariah Vol. 6 No. 2 Desember 2015 
peranan yang sangat strategis untuk menunjang pelaksanaan pembangunan nasional. ${ }^{11}$ Tujuan penulisan artikel ini adalah mendeskripsikan kebijakan pembentukan Undang-undang Pasar Modal Syariah di Indonesia yang di bentuk oleh DPR RI pada tahun 1995 mengenai UndangUndang No. 8 tahun 1995 Tentang Pasar Modal (UUPM).

\section{Metode Penelitian}

Jenis penelitian yang digunakan adalah jenis penelitian hukum normatif atau penelitian hukum kepustakaan dikarenakan penelitian ini ditujukan hanya pada peraturan-peraturan yang tertulis atau bahan-bahan hukum yang lain. Selain itu penelitian ini pun lebih banyak dilakukan terhadap bahan hukum yang bersifat sekunder yang ada diperpustakaan. ${ }^{12}$ Lebih dari itu, penelitian ini cara mengakses dan penelitiannya banyak diambil dari bahan pustaka, ${ }^{13}$ Penelitian hukum normatif ini sepenuhnya menggunakan bahan hukum primer dan bahan hukum sekunder. ${ }^{14}$ Penelitian ini menggunakan pendekatan undang-undang (Statute Approach) yang dilakukan dengan cara menelaah Undang-Undang No. 8 Tahun 1995 dan regulasi yang bersangkut paut dengan isu hukum yang sedang ditangani. Bagi penelitian untuk kegiatan praktis, pendekatan undang-undang ini akan membuka kesempatan bagi peneliti untuk mempelajari adakah konsistensi dan kesesuaian antara suatu undang-undang dengan undang-undang lainnya antara undang-undang dan undang-undang dasar atau antara regulasi dan undang-undang. ${ }^{15}$ Hasil dari telaah tersebut merupakan suatu argumen untuk memecahkan isu yang dihadapi.

Pendekatan penelitian dengan konseptual dan peraturan perundang-undangan. Identifikasi bahan hukum yang telah terkumpul akan diolah sebagai bahan hukum yang informatif sebagai alat untuk menganalisa permasalahan penelitian. ${ }^{16}$ Dengan mempelajari Undang-Undang No.8 Tahun 1995 Tentang Pasar Modal dan Fatwa-fatwa DSN-MUI yang mengatur Pasar Modal Syariah didalam hukum tersebut, peneliti akan menemukan ide-ide yang melahirkan pengertian-pengertian hukum, konsepkonsep hukum, dan asas-asas hukum yang relevan dengan isu yang dihadapi. Pemahaman akan pandangan-pandangan dan doktrindoktrin tersebut merupakan sandaran bagi peneliti dan membangun suatu argumentasi hukum dalam memecahkan isi yang dihadapi. ${ }^{17}$ Bahan hukum primer adalah bahan pustaka yang berisi informasi berupa sumber utama, yang merupakan bahan hukum yang terdiri atas peraturan perundang-undangan, risalah resmi, dan dokumen negara resmi. Adapaun bahan hukum primer dalam penelitian ini adalah Undang-Undang Pasar Modal No. 8 Tahun 1995 tentang Pasar Modal, serta beberapa fatwa MUI yang menjadi regulasi dalam penelitian ini. ${ }^{18}$ Suatu bahan pustaka yang berisi informasi tentang bahan hukum sekunder berupa buku-buku, jurnal, majalah, naskah, dokumen dan sumber literatur lainnya. buku-buku yang meliputi buku tentang Pasar Modal Syariah, buku tentang aspek hukum dalam Pasar Modal Konvensional dan Pasar Modal Syariah serta memanfaatkan bahan-bahan dan artikel-artikel yang dapat diunduh pada website atau situs online lainnya. Dalam penelitian ini, setelah bahan hukum tersebut terkumpul maka bahan tersebut dianalisis untuk mendapatkan konklusi, bentuk dalam teknik analisis bahan hukum adalah content analisis. Dalam analisis jenis ini

\footnotetext{
${ }^{11}$ Dewan Perwakilan Rakyat Republik Indonesia "Arsip Dokumentasi Setjen DPR RI 2012 Risalah Rapat Panitia Khusus Rancangan Undang-Undang Tentang Pasar Modal Tahun 1995", 11

12 Bambang Waluyo, Penelitian Hukum dalam Praktek (Jakarta: Sinar Grafika, 2008), 13

13 Suharsimi Arikunto, Prosedur Penelitian Suatu Pendekatan, Praktek (Jakarta:Rineka Cipta, 2002), 10

14 Amiruddin dan Zainal Asikin, Pengantar Metode Penelitian Hukum (Jakarta: Rajawali Pers, 2006 ), 118.

15 Peter Mahmud Marzuki, Penelitian Hukum, (Jakarta: Kencana, 2007), 93

${ }^{16}$ P.M.Hadjon, Pengkajian Ilmu Hukum Dogmatik (Normatif), (Majalah Yuridika, No.6 tahun IX, FH. Unair Surabaya, 1997)

17 Peter Mahmud Marzuki, Penelitian Hukum (Jakarta:Kencana, 2007), 95

18 Roni Hanitijo Soemitro, Metodologi Penelitian Hukum dan Jurumentri (Jakarta: Ghalia Indonesia, 1990$), 12$.

Jurisdictie: Jurnal Hukum dan Syariah Vol. 6 No. 2 Desember 2015
} 
bahan hukum yang dianalisis disebut sebagai "teks". Content Analisis menunjukkan pada metode analisis yang integratif dan secara konseptual cenderung diarahkan untuk menemukan, mengidentifikasi, dan mengolah bahan hukum untuk memahami makna, signifikasi, dan relevansinya. ${ }^{19}$

\section{Hasil dan Pembahasan \\ Analisis Pembentukan Undang-Undang Pasar Modal Syariah di Tinjau dari Politik Hukum}

Keberadaan pasar modal merupakan suatu realitas dan menjadi fenomena terkini di tengah-tengah kehidupan umat Islam di abad modern ini. Bahkan hampir negara-negara di seluruh penjuru dunia manapun, telah menggunakan pasar modal sebagai instrumen penting ekonomi. Begitu pula pada tataran mikro (firm-level performance), pasar modal telah menarik perhatian banyak kalangan pengusaha dan investor untuk terlibat di dalamnya. Tentu dengan segala konsekuensi baik material maupun spiritual yang banyak diantara mereka tidak menyadari. Bangkitnya ekonomi Islam di belahan dunia saat ini, menjadi fenomena yang menarik dan menggembirakan bagi umat islam pada khususnya serta umat-umat lainnya yang turut merasakan kemaslahatan dari hasil penerapannya. Praktek kegiatan ekonomi konvensional, terutama melalui kegiatan di pasar modal yang mengandung unsur spekulasi (Gharar) dan menjadikan sistem riba sebagai landasan operasionalnya, ternyata telah menjadi hambatan psikologis bagi umat Islam. ${ }^{20}$ Pesatnya perkembangan ekonomi syariah, menuntut adanya instrument keuangan sebagai sarana pendukung. Instrumen keuangan syariah dapat diwujudkan ke dalam berbagai bentuk lembaga pembiayaan seperti halnya lembaga pasar modal syariah. Keberadaannya pasar modal syariah diharapkan akan menjadi media alternatif berinvestasi secara halal melalui pembiayaan usaha di sektor riil. ${ }^{21}$

Dasar pemikiran mengembangkan wacana investasi keuangan melalui pasar modal yang menerapkan prinsip-prinsip syariah berawal dari besarnya peningkatan akumulasi kapital di kalangan umat Islam, baik dalam maupun luar negeri. ${ }^{22}$ Adapun negara yang pertama kali memperkenalkan penerapan prinsip syariah di bidang pasar modal adalah Jordan dan Pakistan. Karena pemerintah Pakistan pada tahun 1980 telah menerbitkan The Madarabas Company dan Madarabas Ordinance. Sedangkan pada tahun 1978, Pemerintah Jordan melalui law No. 13 tahun 1978 telah mengizinkan Jordan Islamic Bank untuk menerbitkan Muqaradah Bond. Izin penerbitan ini kemudian ditindaklanjuti dengan penerbitan Muqaradah Bond Act pada tahun 1981. Di Indonesia secara historis keberadaan pasar modal syariah dimulai dan diperkenalkan pada pertengahan tahun 1997 melalui instrment reksadana syariah. Berkat adanya kerja sama antara PT Bursa Efek Jakarta (BEJ) dengan PT Danareksa Investment Management (DIM) pada bulan Juli 2000 berhasil dibentuk Jakarta Islamic Index (JII). Kemudian pembentukan ini diikuti dengan peluncuran Obligasi Syariah Mudharabah oleh PT. Indosat di penghujung tahun 2002. Namun secara resmi, peluncuran pasar modal syariah di Indonesia terjadi pada tanggal 14 dan 15 Maret 2003, setelah melalui penandatanganan nota kesepahaman (Memorandum of Understanding) antara Bapepam dengan Dewan Syariah Nasional-Majelis Ulama Indonesia (DSN-MUI). ${ }^{23}$

Lembaga yang memiliki kewenangan memfatwakan hukum-hukum syariah terkait dengan lembaga ekonomi dan keuangan adalah para ulama yang terkoordinasi di bawah Dewan Syariah Nasional Majelis Ulama Indonesia (DSNMUI). Dalam kepengurusan DSN-

\footnotetext{
${ }^{19}$ Burhan Bungin, Metode Penelitian Kualitatif:Aktualisassi Metodologi Ke-Arah Ragam Varian Kontemporer, (Jakarta: PT. RajaGrafindo Persada, 2007), 203

${ }^{20}$ Burhanuddin Susamto, Pasar Modal Syariah, (Yogyakarta: UII Press, 2009), 1

${ }^{21}$ Burhanuddin Susamto, Pasar Modal Syariah, 1

${ }^{22}$ Burhanuddin Susamto, Pasar Modal Syariah, 11

${ }^{23}$ Burhanuddin Susamto, Pasar Modal Syariah, 14
}

Jurisdictie: Jurnal Hukum dan Syariah Vol. 6 No. 2 Desember 2015 
MUI, terdapat Badan Pelaksana Harian (BPH) yang keanggotaannya terdiri dari para pakar yang bukan hanya ahli di bidang masing-masing, tetapi juga memiliki komitmen dan pemahaman tentang hukum syariah. Melalui penelitian dan pengkajian secara mendalam terhadap berbagai persoalan, BPH merekomendasikan kepada pimpinan DSN-MUI untuk memberikan fatwa kepada lembaga terkait, sebelum ditindak lanjuti dalam bentuk kebijakan. Dalam hal ini, kesadaran dan pemahaman terhadap prinsip syariah bagi para pelaku kebijakan akan sangat menentukan. ${ }^{24}$

Sebagai tindak lanjut fatwa DSN-MUI, Bapepam juga telah mengeluarkan kebijakan terkait dengan pengembangan pasar modal syariah. Pada tanggal 23 November 2006, Bapepam dan LK melalui Keputusan Ketua Bapepam-LK Nomor Kep-130/BL/2006 (Peraturan Nomor IX.A.13) tentang penerbitan efek syariah dan Keputusan Ketua BapepamLK Nomor Kep- 131/BL/2006 (Peraturan Nomor IX.A.14) tentang akad-akad yang digunakan dalam penerbitan efek syariah. ${ }^{25}$

Dengan mengacu pada beberapa Peraturan Tata Tertib Dewan Perwakilan Rakyat Republik Indonesia yang pernah berlaku, khususnya sebelum Perubahan UUD 1945, serta ketentuan yang terkait dengan kewenangan DPR dalam melaksanakan hak inisiatif, untuk mengajukan usul Rancangan UndangUndang, kemudian ditentukan proses dan mekanisme pengajuan usul inisiatif pengajuan Rancangan Undang-Undang oleh Dewan Perwakilan Rakyat. ${ }^{26}$ Dalam praktek, hak inisiatif pengajuan Rancangan Undang-Undang umumnya datangnya dari presiden. Memang, salah satu faktor penghambat Dewan Perwakilan Rakyat dalam menggunakan hak inisiatif, yang secara politis sukar diwujudkan, disamping faktorfaktor lainnya. ${ }^{27}$

Berdasarkan ketentuan dalam Peraturan Tata Tertib Dewan Perwakilan Rakyat, sebagaimana diatur dalam Keputusan DPR RI Nomor: 10/DPR-RI/III/82- 83, khususnya dalam Pasal 134, menentukan: ${ }^{28}$

“...sekurang-kurangnya 20 orang anggota dan tidak terdiri dari satu fraksi dapat mengusulkan Rancangan Undang-Undang. Apabila usul tersebut diterima Dewan Perwakilan Rakyat, maka diserahkan kepada salah satu komisi, atau rapat Gabungan Komisi, atau Pansus untuk disempurnakan. Setelah disempurnakan, oleh Pimpinan Dewan Perwakilan Rakyat disampaikan kepada Presiden untuk mendapat pembahasan."

Berbeda dengan Peraturan Tata Tertib DPR Tahun 82-83, pada Tata Tertib Tahun 20012002, pengajuan usul Rancangan Undang-Undang oleh Dewan Perwakilan Rakyat, sebagimana diatur dalam pasal 127 dinyatakan bahwa: ${ }^{29}$

“..sekurangnya-kurangnya 10 (sepuluh) orang anggota dapat mengajukan usul Rancangan Undang-Undang. Usul rancangan undangundang, dapat juga diajukan oleh komisi, Gabungan Komisi, atau Badan Legislasi dengan memerhatikan pada program legislasi nasional. Usul Rancangan UndangUndang, beserta keterangan pengusul disampaikan secara tertulis oleh Anggota, Pimpinan Komisi, Pimpinan Gabungan Komisi, atau Badan Legislasi kepada

\footnotetext{
${ }^{24}$ Burhanuddin Susamto, Aspek hukum lembaga keuangan syariah, (Yogyakarta:Graha Ilmu, 2010), 132-133

${ }^{25}$ Burhanuddin Susamto, Aspek Hukum Lembaga, 133

${ }^{26}$ Yuliandri, Asas-Asas Pembentukan Peraturan Perundang-Undangan yang Baik, (Jakarta: PT RajaGrafindo Persada, Cetakan Ke-2, 2010), 78

${ }^{27}$ Yuliandri, Asas-Asas Pembentukan Peraturan Perundang-Undangan, 78

${ }^{28}$ Yuliandri, Asas-Asas Pembentukan Peraturan Perundang-Undangan, 79

${ }^{29}$ Yuliandri, Asas-Asas Pembentukan Peraturan Perundang-Undangan, 79

Jurisdictie: Jurnal Hukum dan Syariah Vol. 6 No. 2 Desember 2015
} 
pimpinan DPR disertai daftar nama dan tanda tangan pengusul serta nama fraksinya."

“..dalam Rapat Paripurna berikutnya setelah usul Rancangan Undang-Undang tersebut diterima oleh Pimpinan DPR, ketua rapat memberitahukan kepada seluruh anggota. Rapat Paripurna memutuskan apakah usul Rancangan UndangUndang tersebut secara prinsip dapat diterima menjadi Rancangan undangUndang usul dari dari DPR atau tidak. Keputusan memberikan penjelasan dan kepada fraksi untuk memberikan pendapatnya. Keputusan dalam rapat paripurna, dapat berupa: persetujuan tanpa perubahan, persetujuan dengan perubahan, atau penolakan.

Selanjutnya, dalam Pasal 46 ayat (3) UU No. 12 Tahun 2011 dinyatakan bahwa ketentuan lebih lanjut mengenai Tata Cara Mempersiapkan RUU di lingkungan DPR RI diatur dengan Peraturan DPR RI. Tata Cara Mempersiapkan RUU sebagaimana dimaksudkan oleh Pasal 46 ayat (3) UU No. 12 Tahun 2011 tersebut diatur dalam Peraturan Tatib DPR RI No. 01 Tahun 2009. RUU yang diajukan oleh Presiden disiapkan oleh menteri atau pimpinan lembaga pemerintah nonkementerian sesuai dengan lingkup tugas dan tanggung jawabnya (ketentuan Pasal 47 ayat (1) UU No. 12 Tahun 2011). ${ }^{30}$ Dalam penyusunan RUU, menteri atau pimpinan lembaga pemerintah nonkementerian terkait membentuk panitia antarkementerian dan/atau antarnonkementerian (ketentuan Pasal 47 ayat (2) UU No. 12 Tahun 2011). Pengharmonisasian, pembulatan, dan pemantapan konsepsi RUU yang berasal dari Presiden dikoordinasikan oleh Menteri Hukum dan Hak Asasi Manusia (ketentuan Pasal 47 ayat (3) UU No. 12 Tahun 2011. ${ }^{31}$ Dari Rapat Panitia Khusus Rancangan Undang-Undang Pasar Modal yang telah dilaksanakan oleh Dewan Perwakilan Rakyat Republik Indonesia pada tahun 1995 yang telah berlalu bahwa rapat tersebut telah memenuhi syarat yang berdasarkan ketentuan dalam Peraturan Tata Tertib Dewan Perwakilan Rakyat Republik Indonesia, sebagaimana diatur dalam Keputusan DPR RI Nomor: 10/DPR-RI /III/82-83, bahwa untuk melakukan Rapat Pansus Rancangan UndangUndang dalam rapat tersebut sekurang-kurang ada 20 orang anggota atau lebih dikutip dari Risalah Rapat Panitia Khusus Rancangan Undang-Undang tentang Pasar Modal:

Sebagaimana hasil musyawarah dari fraksi-fraksi peserta Rapat Panitia Khusus Rancangan Undang-Undang Tentang Pasar Modal yang dilaksanakan oleh DPR RI selaku Ketua Rapat Ir. Abdurrachman Rangkuti pada hari selasa, 11 juli 1995 dalam musyawarah tersebut yang telah di uraikan di atas terdapat beberapa hal yang di sampaikan oleh salah satu peserta sidang yaitu Fraksi Karya Pembangunan ada beberapa hal yang disetujui danharus di cantumkan dalam Peraturan Undang-Undang yang mengatur tentang Pasar Modal di Indonesia yang telah dituangkan dalam Undang-Undang Pasar Modal No. 8 Tahun 1995 Tentang Pasar Modal, yaitu pertama, di dalam ketentuan umum di rumuskan mengenai definisi dari berbagai istilah yang merupakan pemahaman tekhnis untuk membaca rancangan UndangUndang. Meskipun demikian, ada hal prinsip yang seharusnya dijadikan jiwa dari RUU ini yaitu yang menyangkut mengenai "persaingan yang wajar". Mengingat bahwa jiwa dan semangat RUU ini harus senantiasa berlandaskan prinsip persaingan yang wajar tersebut, hl ini harus didefinisikan dengan jelas sehingga terdapat satu pemahaman yang sama mengenai apa yang dimaksud dengan persaingan wajar. Selain itu, ada beberapa hal prinsip yang juga memerlukan definisi, antara lain mengenai apa yang

${ }^{30}$ Aziz Syamsuddin, Proses dan Tekhnik Penyusunan Undang-Undang, 55

${ }^{31}$ Aziz Syamsuddin, Proses dan Tekhnik Penyusunan Undang-Undang, 55

Jurisdictie: Jurnal Hukum dan Syariah Vol. 6 No. 2 Desember 2015 


\section{dimaksud dengan Pasar Modal. Informasi Orang Dalam, Kontrak Pengelolaan} Reksa dana, Manajer Investasi, dan Penjamin Emisi Efek. ${ }^{32}$

Kedua, Mengingat bahwa pasar modal merupakan sumber pembiayaan dunia usaha dan sebagai media investasi bagi para pemodal yang ingin memiliki peranan yang sangat strategis untuk menunjang pelaksanaan pembangunan nasional, selain perlunya diberikan definisi yang jelas tentang pasar modal, di dalam undang-undang ini perlu juga dijelaskan mengenai tujuan pasar modal serta prinsip transparansi di dalam pelaksanaan kegiatannya. Selanjutnya, erat hubungannya dengan sistem perdagangan di pasar sekunder, Fraksi Karya Pembangunan meminta perhatian juga tentang pengaturan sistem perdagangan di Bursa Paralel.

Ketiga, Ketentuan yang mengatur mengenai ganti rugi atas informasi yang tidak benar atau menyesatkan telah didefinisikan sebagai wilayah hukum perdata. Padahal implikasi dari pelanggaran-pelanggaran atas informasi yang tidak benar atau menyesatkan akan memberikan pengaruh yang luas bagi kepercayaan masyarakat yang merupakan jiwa dari eksistensi pasar modal. Berdasarkan hal tersebut, ada baiknya apabila dipertimbangkan bahwa pelanggaran terhadap ketentuan ini diancam dengan hukum pidana, dan tidak hanya menggiring pelanggaran-pelanggaran tersebut ke dalam wilayah hukum perdata.

Keempat, Setiap pihak yang memiliki sekurang-kurangnya 5\% saham Perusahaan Publik atau Emiten wajib melaporkan kepada Bapepam, demikian pula atas setiap perusahaan kepemilikan saham tersebut. Di dalam konteks ini Fraksi Karya Pembangunan berharap agar yang dimaksud dengan Perusahaan Publik atau Emiten tersebut adalah bank yang telah go publik sehingga laporan dimaksud wajib disampaikan pula kepada Bank Indonesia. Hal ini perlu dilakukan mengingat bahwa untuk bank yang telah go publik, Bank Indonesia baru meminta laporan apabila ada prusahaan kepemilikan saham sebesar 35\% dari saham bank yang bersangkutan. Kelima, Salah satu kerawanan bagi negara yang ekonominya sangat terbuka seperti negara kita ialah banyaknya investasi oleh pihak asing di dalam bentuk investasi portofolio. Investasi ini dapat berpindah setiap waktu dari negara yang bersangkutan, contohnya Mexico. Berhubung dengan hal tersebut, Fraksi Karya Pembangunan menyarankan agar bagian kepemilikan saham oleh pihak asing dibatasi dengan Undang-undang atau sekurang-kurangnya diberikan aturan di dalam Undang-unang ini dan/atau diatur di dalam suatu Peraturan Pemerintah. ${ }^{33}$

Keenam, Penawaran kobinasi merupakan hal baru di dalam kegiatan pasar modal di Indonesia sehingga banyak menimbulkan ambiguitas. Meskipun demikian, Fraksi Karya Pembangunan berkeyakinan bahwa penawaran kombinasi akan menjadi trend penjualan efek pada masa mendatang, terutama dengan semakin canggihnya arus informasi dan telekomunikasi antarlokasi bursa efek, baik di dalam negeri maupun di luar negeri. Sehubungan dengan hal tersebut, penawaran kombinasi bagi emiten domestik perlu mendapat pengaturan di dalam undang-undang ini. Di pihak lain, pengaturan untuk emiten asing harus diatur tersendiri sebab masih banyak aspek yang diperlukan pengaturannya. Ketujuh, Di dalamnya prakteknya perusahaan publik (terutama bagi "perusahaan publik murni", yang didalamnya tidak terdapat pemegang saham mayoritas), jika akan mengadakan RUPS untuk perubahan anggaran dasar atau untuk tindakan lain yang memerlukan persetujuan dari sedikitnya $2 / 3$ atau lebih dari pemegang saham, biasanya akan mengalami kesulitan untuk mencapai kuorum sebagaimana disyaratkan. Sehubungan dengan hal tersebut dan supaya terdapat kepastian pelaksanaan RUPS, di dalam Undang-Undang Pasar Modal atau peraturan

\footnotetext{
${ }^{32}$ Dewan Perwakilan Rakyat Republik Indonesia "Arsip Dokumentasi Setjen DPR RI 2012 Risalah Rapat Panitia Khusus Rancangan Undang-Undang Tentang Pasar Modal Tahun 1995”, 10

${ }^{33}$ Dewan Perwakilan Rakyat Republik Indonesia "Arsip Dokumentasi Setjen DPR RI 2012 Risalah Rapat Panitia Khusus Rancangan Undang-Undang Tentang Pasar Modal Tahun 1995”, 11

Jurisdictie: Jurnal Hukum dan Syariah Vol. 6 No. 2 Desember 2015
} 
pelaksanaannya harus dicantumkan wewenang Bapepam untuk memberikan persetujuan kepada perusahaan Publik guna mengadakan RUPS ketiga dengan persyaratan kuorum di dalam jumlah tertentu jika di dalam RUPS pertama dan kedua tidak tercapai kuorum.

Kedelapan, bagi Perusahaan Publik atau Emiten berlaku ketentuan mengenai sanksi atas berbagai pelanggaran peraturan pasar modal. Sanksi tersebut dapat dijatuhkan kepada Perusahaan dan/atau pengurusnya. Secara garis besar sanksi dapat dibedakan di dalam tiga bentuk yaitu sanksi administratif, sanksi perdata, dan sanksi pidana. Hal yang penting berkaitan dengan dengan sanksi atas pelanggaran adalah ketentuan mengenai lembaga class action dan derivative action. Terjadinya class action biasanya disebabkan oleh pelanggaran yang dilakukan oleh seseorang/badan hukum yang telah merugikan banyak pihak dan kerugian yang diderita pihak yang dirugikan per individu tidak efisien dibandingkan dengan biaya penuntutan/gugatan. Derivative action biasanya dilakukan oleh pemegang saham suatu perusahaan yang melakukan penuntutan/gugatan atas nama perusahaan. Sehubungan dengan hal yang sangat prinsip tersebut. Fraksi Karya Pembangunan berharap agar hal-hal yang berhubungan dengan berbagai bentuk sanksi sebagaimana disebutkan di dalam RUU Pasar Modal lebih disempurnakan dan/atau dilengkapi.

Kesembilan, Salah satu tujuan utama pasar modal adalah untuk ikut menyukseskan pembangunan nasional yang adil dan dan makmur melalui peran Pasar Modal sebagai sumber pembiayaan bagi dunia usaha. Guna menjamin kelestarian fungsi dan kesinambungan lingkungan hidup sebagaimana diamanatkan di dalam GBHN, bagi setiap pihak yang melakukan kegiatan di pasar modal, terutama Perusahaan Publik sudah pada tempatnya melakukan upaya pengintegrasian secara menyuluruh keterpaduan di dalam pengelolaan lingkungan hidup di setiap tahapan pembangunan, mulai dari tahap perumusan kebijaksanaan, perencanaan, pelaksanaan, sampai dengan tahap pengendalian. Dengan demikian, diharapkan pembangunan dan hasil-hasilnya dapat dinikmati secara lebih adil dan merata oleh masyarakat yang didukung oleh stabilitas nasional yang mantap dan dinamis melalui pembangunan yang berkelanjutan dengan memperhatikan keletarian fungsi lingkungan hidup. Di dalam hubungan ini Fraksi Karya Pembangunan berharap agar di dalam undangundang ini diperhatikan juga beberapa prinsip yang memuat atau mengatur keharusan perusahaan publik atau emiten untuk senantiasa melakukan upaya pengintegrasian secara menyuluruh dan terpadu di dalam pengelolaan lingkungan hidup. ${ }^{34}$

Setelah Rapat Panitia Khusus ke-1 selesai maka akan dilanjutkan rapat Panitia Khusus Ke-2 akan dilaksanakan untuk pembicaraan dengan agenda sebagai berikut:

\section{“..Dalam hal Rancangan Undang-Undang berasal dari pemerintah, maka anggota menyampaikan pemandangan umum yang membawakan suara fraksi terhadap Rancangan Undang-Undang, dan kemudian pemerintah menjawab terhadap pemandangan umum dimaksud. Dalam hal rancangan berasal dari usul inisiatif, terlebih dahulu pemerintah menyampaikan tanggapan dan kemudian diikuti dengan jawaban atas tanggapan dimaksud." 35}

Selanjutnya, dalam ketentuan pembahasan RUU di DPR RI diatur dalam Pasal 65 s.d Pasal 71 UU No. 12 Tahun 2011, yaitu terangkum dalam Bab VII (Pembahasan dan Pengesahan Rancangan Undang-Undang), Bagian "Pembahasan Rancangan UndangUndang". ${ }^{36}$ Pasal 65 UU No. 12 Tahun 2011: (1) Pembahasan Rancangan Undang-Undang dilakukan oleh DPR RI bersama Presiden atau menteri yang ditugasi. (2) Pembahasan Rancangan Undang-Undang sebagaimana dimaksud pada ayat (1) yang berkaitan dengan (a)

\footnotetext{
${ }^{34}$ Dewan Perwakilan Rakyat Republik Indonesia "Arsip Dokumentasi Setjen DPR RI 2012 Risalah Rapat

Panitia Khusus Rancangan Undang-Undang Tentang Pasar Modal Tahun 1995”, 13

${ }^{35}$ Yuliandri, Asas-Asas Pembentukan Peraturan Perundang-Undangan, 81

${ }^{36}$ Aziz Syamsuddin, Proses dan Tekhnik Penyusunan Undang-Undang, 55
}

Jurisdictie: Jurnal Hukum dan Syariah Vol. 6 No. 2 Desember 2015 
otonomi daerah, (b) hubungan pusat dan daerah, (c) pembentukan, pemekaran, dan penggabungan daerah, (d) pengelolaan sumber daya alam dan sumber daya ekonomi lainnya, dan (e) perimbangan keuangan pusat dan daerah, dilakukan dengan mengikutsertakan DPD. (3) Keikutsertaan DPD dalam pembahasan Rancangan Undang-Undang sebagaimana dimaksud pada ayat (2) dilakukan hanya pada pembicaraan tingkat I. (4) Keikutsertaan DPD dalam pembahasan Rancangan Undang-Undang sebagaimana dimaksud pada ayat (2) dan ayat (3) diwakili oleh alat kelengkapan yang membidangi materi muatan Rancangan UndangUndang yang dibahas. (5) DPD memberikan pertimbangan kepada DPR atas Rancangan UndangUndang tentang Anggaran Pendapatan dan Belanja Negara dan Rancangan UndangUndang yang berkaitan dengan pajak, pendidikan, dan agama.

Menurut ketentuan Pasal 66 UU No. 12 Tahun 2011, pembahasan RUU di DPR RI dilakukan melalui 2 (dua) tingkat pembicaraan. Dua tingkat pembicaraan tersebut atas: a) pembicaraan Tingkat I dalam rapat komisi, rapat gabungan komisi, rapat Badan Legislasi, rapat Badan Anggaran, atau rapat Panitia Khusus; dan b) Pembicaraan Tingkat II dalam rapat paripurna DPR RI. (ketentuan Pasal 67 UU No. 12 Tahun 2011). Hal ihwal Pembicaraan Tingkat I proses pembahasan RUU di DPR RI diatur dalam ketentuan Pasal 68 ayat (1) s.d (6) UU No. 12 Tahun 2011. Pembicaraan Tingkat I mengagendakan sejumlah kegiatan, yaitu pengantar musyawarah, pembahasan daftar inventarisasi masalah, dan penyampaian pendapat mini. ${ }^{37}$ Dalam kegiatan pengantar musyawarah berisikan beberapa hal yaitu: a) DPR memberikan penjelasan dan Presiden menyampaikan pandangan jika RUU berasal dari DPR, b) DPR memberikan penjelasan Presiden dan DPD menyampaikan pandangan jika RUU yang berkaitan dengan kewenangan DPD berasal dari DPR, c) Presiden memberikan penjelasan dan fraksi memberikan pandangan jika RUU berasal dari Presiden; atau d) Presiden memberikan penjelasan, fraksi dan DPD menyampaikan pandanga jika RUU yang berkaitan dengan kewenangan DPD berasal dari Presiden. ${ }^{38}$

Beberapa pendapat Pengantar Musyawarah yang telah disampaikan dalam Rapat Panitia Khusus Rancangan Undang-Undang tentang Pasar Modal untuk membahas masalah peraturan untuk mengatur Pasar Modal di Indonesia, kutipan dari Rapat Panitia Khusus Rancangan Undang-Undang Tentang Pasar Modal dapat dilihat pada lampiran. Selanjutnya dalam Pembicaraan Tingkat II proses pembahasan RUU di DPR RI diatur dalam ketentuan Pasal 69 ayat (1), (2), \& (3) UU No. 12 Tahun 2011. Pembicaraan Tingkat II merupakan pengambilan keputusan dalam rapat paripurna DPR RI yang beragendakan sejumlah kegiatan sebagai berikut: ${ }^{39}$ a) Penyampaian laporan yang berisi proses, pendapat mini fraksi, pendapat mini DPD RI, dan hasil pembicaraan tingkat I; b) Pernyataan persetujuan atau penolakan dari tiaptiap fraksi dan anggota secara lisan yang diminta oleh pimpinan rapat paripurna; dan c) Penyampaian pendapat akhir Presiden yang dilakukan oleh menteri yang ditugasi.

Melihat dari pendekatan yang digunakan dalam Rancangan Undangundang tentang Pasar Modal dibagi dua, yaitu Pendekatan Kelembagaan dan Pendekatan Aktivitas. Dari pendekatan itu maka di dapat masalah untuk merancang Undang-Undang tentang Pasar Modal yang sudah di tuangkan dalam Daftar Inventarisasi Masalah (DIM) untuk melakukan Proses Pembahasan selanjutnya dalam Pembentukan Undang-Undang Tentang Pasar Modal. Adapun Daftar Inventarisasi Masalah tersebut, yakni pertama, menanggapi pokok pikiran yang disampaikan FKP pada halaman 3 dari Pengantar Musyawarah mengenai perlunya diberikan definisi "persaingan yang wajar", dapat dijelaskan bahwa pengertian "persaingan yang wajar" pada dasarnya merupakan jiwa dan semangat dari Rancangan Undang-Undang Pasar Modal

\footnotetext{
${ }^{37}$ Aziz Syamsuddin, Proses dan Tekhnik Penyusunan Undang-Undang, 58

${ }^{38}$ Aziz Syamsuddin, Proses dan Tekhnik Penyusunan Undang-Undang, 59

${ }^{39}$ Aziz Syamsuddin, Proses dan Tekhnik Penyusunan Undang-Undang, 59

Jurisdictie: Jurnal Hukum dan Syariah Vol. 6 No. 2 Desember 2015
} 
yang tercermin dalam Batang Tubuh RUU Pasar Modal sebagaimana dapat dilihat dari keharusan adanya transparansi, kewajiban pelaporan, larangan-larangan seperti manipulasi pasar, insider trading, penyampaian informasi yang tidak benar dan menyesatkan, dan pengaturan mengenai sanksi baik yang bersifat administratif, perdata, maupun pidana. ${ }^{40}$

Kedua, menanggapi pokok pikiran yang disampaikan FKP pada halaman 3 dari Pengantar Musyawarah mengenai perlunya penjelasan tujuan Pasar Modal serta prinsip transparansi didalam pelaksanaan kegiatannya, dapat disampaikan bahwa kami pada prinsipnya sependapat dengan usulan tersebut, namun penempatannya seyogyanya dimuat dalam konsiderans "Menimbang" dan dalam Penjelasan Umum. ${ }^{41}$ Selanjutnya mengenai pengaturan sistem perdagangan di Bursa Paralel, dapat dijelaskan bahwa pada dasarnya bursa tidak dibedakan antara bursa yang satu dengan bursa yang lainnya. Perbedaannya terletak pada persyaratan pencatatan dan perdagangan di kedua bursa tersebut. Oleh karena itu, pengaturan mengenai sistem perdagangan di Bursa Paralel seperti halnya bursa lainnya,diserahkan kepada masing-masing bursa selaku "Self Regulatory Organization" (SRO). Walaupun demikian, Bursa Paralel yang berfungsi menampung pencatatan bagi perusahaan menengah dan kecil akan tetap dipertahankan eksistensinya sebagai bagian dari Kebijaksanaan Pemerintah, kendatipun Bursa Paralel akan bergabung (Merger) dengan Bursa Efek Surabaya. ${ }^{42}$

Ketiga, menanggapi pokok pikiran yang disampaikan FKP pada halaman 4 dari Pengantar Musyawarah mengenai perlunya dijatuhkan sanksi pidana terhadap pelanggaranpelanggaran atas informasi yang tidak benar atau menyesatkan disamping sanksi perdata, dengan ini disampaikan bahwa kami sependapat dengan FKP, dan sebenarnya hal ini telah ditampung dalam Pasal 89 jo. Pasal 103 Rancangan Undang-Undang Pasar Modal. Selanjutnya, dapat dijelaskan pula bahwa tidak semua pelanggaran terhadap ketentuan Pasar Modal harus dikenakan sanksi pidana, kecuali apabila perbuatan tersebut terjadi akibat penipuan, pemalsuan, atau hal-hal sejenisnya, atau apabila tindakan tersebut sedemikian merugikan kepentingan publik. Dalam hal masyarakat telah menerima ganti rugi dan perbuatan tersebut tidak merugikan Pasar Modal secara keseluruhan, maka kiranya tidak perlu dilanjutkan dengan penuntutan pidana. Dapat dikemukakan bahwa prinsipprinsip seperti ini pun berlaku di negara-negara lain.

Keempat, menanggapi pokok pikiran yang disampaikan FKP pada halaman 4 dari Pengantar Musyawarah menegenai perlu diwajibkannya setiap Pihak yang memiliki 5\% atau lebih saham Bank yang telah Go Public untuk melapor kepada Bank Indonesia disamping kepada bapepam, dapat disampaikan bahwa pengaturan mengenai hal tersebut kiranya cukup diatr dalam peraturan yang lebih rendah sesuai dengan jiwa dan semangat yang terkandung dalam pasal 113 rancangan Undang-Undang pasar Modal. ${ }^{43}$ Kelima, menanggapi pokok pikiran yang disampaikan FKP pada halaman 4 dari Pengantar Musyawarah mengenai perlunya pembatasan pemilikan pihak asing didalam Undang-Undang atau Peraturan Pemerintah, menurut hemat kami kiranya hal tersebut perlu dikaji lebih lanjut dan pengkajian ini harus mempertimbangkan hal-hal sebagai berikut: a) Keterbatasan pemodal dalam negeri; b) Masuknya pemodal asing akan memperkuat struktur permodalan perusahaan-perusahaan di Indonesia; c) Sejalan dengan Trend Liberalisasi dalam perdagangan dan investasi, maka

\footnotetext{
${ }^{40}$ Dewan Perwakilan Rakyat Republik Indonesia "Arsip Dokumentasi Setjen DPR RI 2012 Risalah Rapat

Panitia Khusus Rancangan Undang-Undang Tentang Pasar Modal Tahun 1995”, 42

${ }^{41}$ Dewan Perwakilan Rakyat Republik Indonesia "Arsip Dokumentasi Setjen DPR RI 2012 Risalah Rapat Panitia Khusus Rancangan Undang-Undang Tentang Pasar Modal Tahun 1995”, 43

42 Dewan Perwakilan Rakyat Republik Indonesia "Arsip Dokumentasi Setjen DPR RI 2012 Risalah Rapat

Panitia Khusus Rancangan Undang-Undang Tentang Pasar Modal Tahun 1995”, 43

${ }^{43}$ Dewan Perwakilan Rakyat Republik Indonesia "Arsip Dokumentasi Setjen DPR RI 2012 Risalah Rapat

Panitia Khusus Rancangan Undang-Undang Tentang Pasar Modal Tahun 1995”, 43
}

Jurisdictie: Jurnal Hukum dan Syariah Vol. 6 No. 2 Desember 2015 
kecenderungan Pasar Modal di dunia, termasuk di negara-negara berkembang, akan semakin terbuka.

Keenam, menanggapi pokok pikiran yang disampaikan FKP pada halaman 4 dari Pengantar Musyawarah mengenai perlunya pengaturan mengenai penawaran kombinasi bagi emiten domestik dalam Rancangan Undang-Undang Pasar Modal, dapat kami jelaskan bahwa penawaran kombinasi pada prinsipnya merupakan penawaran umum, dimana ketentuan mengenai penawaran umum telah diatur dalam Rancangan Undang-Undang Pasar Modal (Pasal 69). Selanjutnya mengenai pengaturan untuk emiten asing dapat disampaikan bahwa pengertian Emiten dalam Rancangan Undang-Undang Pasar Modal ini tidak dibatasi hanya pada emiten domestik tetapi juga berlaku bagi emiten asing. Pengaturan lebih lanjut mengenai hal ini seyogyanya diatur dalam peraturan pelaksanaan Undang-Undang Pasar Modal. ${ }^{44}$

Ketujuh, menanggapi pokok pikiran yang disampaikan FKP pada halaman 5 dari Pengantar Musyawarah mengenai perlunya penyempurnaan pengaturan mengenai sanksi dalam Rancangan Undang-Undang ini, khususnya mengenai lembaga Class Action, dengan ini disampaikan bahwa Pemerintah dapat memahami usulan FKP. Namun jika hal tersebut dimasukkan kedalam Rancangan Undang-Undang Pasar Modal, maka hal tersebut secara operasional belum dapat diterapkan mengingat pada saat ini Hukum Acara Perdata kita belum memungkinkannya. Pemerintah dapat memahami apabila Class Action dimasukkan dalam Rancangan Undang-Undnag Pasar Modal itu memang merupakan suatu langkah yang antisipatif. Selanjutnya mengenai Lembaga Derivative Action, dapat kami sampaikan bahwa hal tersebut telah diatur dalam Undang-Undang Nomor 1 Tahun 1995 tentang Perseroan Terbatas. Kedelapan, menanggapi pokok pikiran yang disampaikan FKP pada halaman 6 dari Pengantar Musyawarah mengenai perlunya pengaturan mengenai keharusan Perusahaan Publik memperhatikan kelestarian lingkungan hidup, dapat kami jelaskan bahwa pengaturan lingkungan hidup seyogyanya diatur dalam peraturan perundang-undangan yang berkaitan dengan Lingkungan Hidup, sehingga dapat berlaku untuk seluruh perusahaan, tidak hanya untuk Perusahaan Publik atau Emiten. ${ }^{45}$

Setelah suatu Rancangan Undang-Undang disetujui untuk menjadi Undang-Undang, proses berikutnya ialah: pengesahan, pengundangan, dan penyebarluasan (sosialisasi). RUU yang telah disetujui bersama oleh DPR RI dan Presiden disampaikan oleh Pimpinan DPR RI kepada Presiden untuk disahkan menjadi UU. Penyampaian RUU tersebut dilakukan dalam jangka waktu paling lama 7 (tujuh) hari terhitung sejak tanggal persetujuan bersama (ketentuan Pasal 72 ayat (1) dan (2) UU No. 12 Tahun 2011). Tenggang waktu 7 (tujuh) hari dianggap layak untuk mempersiapkan segala hal yang berkaitan dengan tekhnik penulisan RUU ke Lembaran Resmi Presiden sampai dengan penandatanganan pengesahan UU oleh Presiden dan penandatanganan sekaligus Pengundangan ke Lembaran Negara Republik Indonesia oleh menteri yang menyelenggarakan urusan pemerintah di bidang hukum (Penjelasan Pasal 72 ayat (2) UU No. 12 Tahun 2011). ${ }^{46}$ RUU disahkan oleh Presiden dengan membubuhkan tanda tangan dalam jangka waktu paling lama 30 (tiga puluh) hari terhitung sejak RUU tersebut disetujui bersama oleh DPR RI dan Presiden (ketentuan Pasal 73 ayat (1) UU No. 12 Tahun 2011). Batas waktu 30 (tiga puluh) hari sesuai dengan ketentuan Pasal 20 ayat (5) UUD 1945 (Perubahan). Bagaimanakah keabsahan RUU yang telah disetujui bersama oleh DPR RI dan Presiden tersebut tidak ditandatangani oleh Presiden dalam waktu 30 (tiga

\footnotetext{
${ }^{44}$ Dewan Perwakilan Rakyat Republik Indonesia "Arsip Dokumentasi Setjen DPR RI 2012 Risalah Rapat Panitia Khusus Rancangan Undang-Undang Tentang Pasar Modal Tahun 1995”, 44

${ }^{45}$ Dewan Perwakilan Rakyat Republik Indonesia "Arsip Dokumentasi Setjen DPR RI 2012 Risalah Rapat Panitia Khusus Rancangan Undang-Undang Tentang Pasar Modal Tahun 1995”, 45

${ }^{46}$ Aziz Syamsuddin, Proses dan Tekhnik Penyusunan Undang-Undang, 62

Jurisdictie: Jurnal Hukum dan Syariah Vol. 6 No. 2 Desember 2015
} 
puluh) hari? Jawabannya adalah RUU tersebut tetap sah menjadi UU dan wajib diundangkan, sebagaimana diatur dalam ketentuan Pasal 73 ayat (2) UU No. 12 Tahun 2011:

"Dalam hal Rancangan Undang-Undang sebagaimana dimaksud pada ayat (1) tidak ditandatangani oleh Presiden dalam waktu paling lama 30 (tiga puluh) hari terhitung sejak Rancangan Undang-Undang tersebut disetujui bersama, Rancangan Undang-Undang tersebut sah menjadi Undang-Undang dan wajib diundangkan.

Dalam hal sahnya RUU sebagaimana dimaksud ayat (2), kalimat pengesahannya berbunyi: Undang-Undang ini dinyatakan sah berdasarkan ketentuan Pasal 20 ayat (5) Undang-Undang Dasar Negara Republik Indonesia Tahun 1945. ${ }^{47}$ Kalimat pengesahan tersebut harus dibubuhkan pada halaman terakhir UU sebelum pengundangan naskah UU ke dalam Lembaran Negara Republik Indonesia (ketentuan Pasal 73 ayat (3) dan (4) UU No. 12 Tahun 2011).

Setelah RUU disahkan maka tahap selanjutnya adalah tahap pengundangan UndangUndang yang diatur dalam Ketentuan UU No. 12 Tahun 2011. Maka setiap Undang-Undang yang baru disahkan harus diundangkan dengan menempatkannya dalam lembaran-lembaran resmi negara, yaitu (a) lembaran Negara Republik Indonesia dan (b) Tambahan Lembaran Negara Republik Indonesia (Pasal 81 UU No. 12 Tahun 2011). ${ }^{48}$ Dengan diundangkannya UU dalam lembaran resmi tersebut, maka setiap orang dianggap telah mengetahuinya. Selain UU, Peraturan Perundang-undangan lainnya yang diundangkan dalam Lembaran Negara Republik Indonesia, meliputi: a. Peraturan Pemerintah Pengganti Undang-Undang; b. Peraturan Pemerintah; c. Peraturan Presiden; dan d. Peraturan Perundang-Undangan lain menurut Peraturan perundangUndangan yang berlaku harus diundangkan dalam Lembaran Negara Republik Indonesia (Pasal 82 UU No. 12 Tahun 2011).

Pengundangan Undang-Undang dalam Lembaran Negara Republik Indonesia dilaksanakan oleh menteri yang menyelenggarakan urusan Pemerintah dibidang hukum (Pasal 85 UU No. 12 Tahun 2011). Pada dasarnya, setiap Undang-Undang mulai berlaku dan memiliki kekuatan mengikat pada tanggal diundangkan, kecuali ditentukan lain di dalam Undang-Undang yang bersangkutan (Pasal 87 UU No. 12 Tahun 2011). ${ }^{49}$ Berlakunya Undang-Undang yang tidak sama dengan tanggal pengundangannya, dimungkinkan, untuk persiapan sarana dan prasarana serta kesiapan aparatur pelaksanaan UU tersebut (Penjelasan Pasal 87 UU No. 12 Tahun 2011). ${ }^{50}$ Tahap terakhir penyebarluasan Undang-Undang yang diatur dalam Ketentuan Undang-Undang No. 12 Tahun 2011. Tahap penyebarluasan dalam proses pembentukan Undang-Undang tidak hanya terbatas pada informasi tentang pengundangan Undang-Undang, melainkan mencakup juga informasi tentang proses penyusunan Prolegnas, penyusunan RUU, dan dinamika pembahasan RUU. Penyebarluasan dilakukan untuk memberikan informasi dan/atau memperoleh masukan masyarakat serta para pemangku kepentingan (Pasal 88 ayat (1) dan (2) UU No.12 Tahun 2011).

Menurut bagian Penjelasan untuk Pasal 88 ayat (1) Undang-Undang No. 12 Tahun 2011, yang dimaksud dengan "Penyebarluasan" adalah kegiatan menyampaikan informasi kepada masyarakat mengenai Prolegnas, RUU yang sedang disusun, dibahas, dan yang telah diundangkan agar masyarakat dapat memberikan masukan atau tanggapan terhadap UndangUndang tersebut atau memahami Undang-Undang yang telah diundangkan. Kegiatan penyebarluasan tersebut dilakukan, misalnya, melalui media elektronik dan/atau media

\footnotetext{
${ }^{47}$ Aziz Syamsuddin, Proses dan Tekhnik Penyusunan Undang-Undang, 63

${ }^{48}$ Aziz Syamsuddin, Proses dan Tekhnik Penyusunan Undang-Undang, 65

${ }^{49}$ Aziz Syamsuddin, Proses dan Tekhnik Penyusunan Undang-Undang, 65

${ }^{50}$ Aziz Syamsuddin, Proses dan Tekhnik Penyusunan Undang-Undang, 65
}

Jurisdictie: Jurnal Hukum dan Syariah Vol. 6 No. 2 Desember 2015 
cetak. $^{51}$ Pasal 89 ayat (1), (2), dan (3) UU No. 12 Tahun 2011 merumuskan: 1) Penyebarluasan Prolegnas dilakukan bersama oleh DPR dan Pemerintah yang dikoordinasikan oleh alat kelengkapan DPR yang khusus menangani bidang legislasi; 2) Penyebarluasan Rancangan Undang-Undang yang berasal dari DPR dilaksanakan oleh komisi/panitia/badan/alat kelengkapan DPR yang khusus menangani bidang legislasi; 3) Penyebarluasan Rancangan Undang-Undang yang berasal dari Presiden dilaksanakan oleh instansi pemrakarsa.

Pasal 90 ayat (1) dan (2) UU No. 12 Tahun 2011 merumuskan: 1) Penyebarluasan Undang-Undang yang telah diundangkan dalam Lembaran Negara Republik Indonesia dilakukan secara bersama-sama oleh DPR dan Pemerintah. 2) Penyebarluasan UndangUndang sebagaimana dimaksud pada ayat (1) dapat dilakukan oleh DPD sepanjang berkaitan dengan otonomi daerah, hubungan pusat dan daerah, pembentukan dan pemekaran serta penggabungan daerah, pengelolaan sumber daya alam dan sumber daya ekonomi lainnnya, serta yang berkaitan dengan perimbangan keuangan pusat dan daerah. Dari hasil Rapat Panitia Khusus Rancangan Undang-Undang tentang asar Modal yang di Pimpin oleh Ir. Abdurrachman Rangkuti selaku ketua Rapat maka telah didapatkan Undang-Undang yang khusus mengatur Pasar Modal maka sekarang Pasar Modal telah memiliki Undang-Undang tersendiri yang mengaturnya yaitu Undang-Undang No. 8 Tahun1995 tentang Pasar Modal. Rapat itutup tepat pada pukul 11.00 WIB tanggal 25 agustus 1995 dan rapat disetujui oleh semua Fraksi yang menghadiri rapat tersebut. ${ }^{52}$

\section{Kesimpulan}

Terbentuknya Undang-Undang No. 8 Tahun 1995 tentang Pasar Modal dari pendekatan yang digunakan dalam Rancangan Undang-undang tentang Pasar Modal dibagi dua, yaitu Pendekatan Kelembagaan dan Pendekatan Aktivitas. Dari pendekatan itu maka di dapat masalah untuk merancang Undang-Undang tentang Pasar Modal yang sudah di tuangkan dalam Daftar Inventarisasi Masalah (DIM) untuk melakukan Proses Pembahasan selanjutnya dalam Pembentukan Undang-Undang Tentang Pasar Modal. a. Berbicara mengenai pendekatan yang ditempuh dalam menyusun Rancangan Undang-Undang tentang Pasar Modal ini, dapat kiranya kami sampaikan bahwa secara garis besar pendekatannya dapat dibagi dua, yaitu Pendekatan Kelembagaan dan Pendekatan Aktivitas. Pertimbangan memilih untuk memilih Pendekatan Kelembagaan adalah karena keberadaan unsur lembaga terasa sangat kuat didalam pasal-pasal yang ada. Sebagai contoh: Bapepam adalah sebagai lembaga pengawas, Bursa Efek bertindak sebagai lembaga yang menyelenggarakan pasar sekunder, lembaga Kliring dan Penjaminan serta Lembaga Penyimpanan dan Penyelesaian bertindak sebagai lembaga yang menyelesaikan transaksi bursa, serta keberadaan lembaga-lembaga lainnya seperti Lembaga Penunjang Pasar Modal, dan profesi penunjang Pasar Modal. Faktor lainnya dari Pengantar Musyawarah mengenai perlunya dijatuhkan sanksi pidana terhadap pelanggaran-pelanggaran atas informasi yang tidak benar atau menyesatkan disamping sanksi perdata. Sementara Pendekatan aktivitas dapat dilihat dari pasal-pasal di dalam Rancangan Undang-Undang ini memuat aktivitas dari setiap lembaga sebagaimana disebutkan diatas. b. Faktor lainnya secara aspek sosiologisnya tercermin sangat kuat dari cakupan pihak-pihak yang kelak diatur oleh Undang-Undang ini yang mencakup seluruh pelaku Pasar Modal, yaitu setiap pihak yang mempunyai kepentingan dengan aktivitas kepasar modalan dan perusahaan publik.

\footnotetext{
${ }^{51}$ Aziz Syamsuddin, Proses dan Tekhnik Penyusunan Undang-Undang, 66

${ }^{52}$ Dewan Perwakilan Rakyat Republik Indonesia “Arsip Dokumentasi Setjen DPR RI 2012 Risalah Rapat Panitia Khusus Rancangan Undang-Undang Tentang Pasar Modal Tahun 1995”, 495

Jurisdictie: Jurnal Hukum dan Syariah Vol. 6 No. 2 Desember 2015
} 


\section{Daftar Pustaka}

Amiruddin dan Zainal Asikin. Pengantar Metode Penelitian Hukum. Jakarta: Rajawali Pers, 2006

Arikunto, Suharsimi. Prosedur Penelitian Suatu Pendekatan, Praktek. Jakarta:Rineka Cipta, 2002

Bungin, Burhan. Metode Penelitian Kualitatif:Aktualisassi Metodologi Ke-Arah Ragam Varian Kontemporer. Jakarta: PT. RajaGrafindo Persada, 2007

Dewan Perwakilan Rakyat Republik Indonesia “Arsip Dokumentasi Setjen DPR RI 2012

Risalah Rapat Panitia Khusus Rancangan Undang-Undang Tentang Pasar Modal Tahun 1995"

Hadjon, P.M. Pengkajian Ilmu Hukum Dogmatik (Normatif). Majalah Yuridika. No.6 tahun IX. FH. Unair Surabaya, 1997

Indrati, Maria Farida. Ilmu Perundang-Undangan 2 "Proses dan Tekhnik Pembentukannya". Yogyakarta:Penerbit Kanisius, 2007

Latif, Abdul dan Hasbi Ali. Politik Hukum. Jakarta: Sinar Grafika, 2010

Marzuki, Peter Mahmud. Penelitian Hukum. Jakarta: Kencana, 2007

Nasarudin, M. Irsan dan Indra Surya. Aspek Hukum Pasar Modal Indonesia. Jakarta:Kencana, 2008

Rodoni, Ahmad dan Abdul Hamid, Lembaga Keuangan Syariah. Jakarta Zikrul Hakim, 2008

Susamto, Burhanuddin . Aspek Hukum Lembaga Keuangan Syariah. Yogyakarta:Graha Ilmu, 2010

Pasar Modal Syariah. Yogyakarta: UII Press, 2009

Soemitro, Roni Hanitijo. Metodologi Penelitian Hukum dan Jurumentri. Jakarta: Ghalia Indonesia, 1990

Sudarsono, Heri. Bank dan Lembaga Keuangan Syariah Deskripsi dan Illustrasi . Yogyakarta: Ekonisia, 2007

Waluyo, Bambang. Penelitian Hukum dalam Praktek. Jakarta: Sinar Grafika, 2008

Yuliandri. Asas-Asas Pembentukan Peraturan Perundang-Undangan Yang Baik. Jakarta: PT RajaGrafindo Persada, Cetakan Ke-2, 2010 